\title{
Potential of antimicrobial volatile organic compounds to control Sclerotinia sclerotiorum in bean seeds
}

\author{
Maurício Batista Fialho(1), Maria Heloisa Duarte de Moraes $^{(1)}$, Annelise Roberta Tremocoldi ${ }^{(1)}$ \\ and Sérgio Florentino Pascholati ${ }^{(1)}$
}

\begin{abstract}
(1)Universidade de São Paulo, Escola Superior de Agricultura Luiz de Queiroz, Departamento de Fitopatologia e Nematologia, Caixa Postal 09, CEP 13418-900 Piracicaba, SP, Brazil. E-mail: fialhomb@hotmail.com, mhdmorae@esalq.usp.br, annetremocoldi@hotmail.com, sfpascho@esalq.usp.br
\end{abstract}

\begin{abstract}
The objective of this work was to evaluate the potential of an artificial mixture of volatile organic compounds (VOCs), produced by Saccharomyces cerevisiae, to control Sclerotinia sclerotiorum in vitro and in bean seeds. The phytopathogenic fungus was exposed, in polystyrene plates, to an artificial atmosphere containing a mixture of six VOCs formed by alcohols (ethanol, 3-methyl-1-butanol, 2-methyl-1-butanol and phenylethyl alcohol) and esters (ethyl acetate and ethyl octanoate), in the proportions found in the atmosphere naturally produced by yeast. Bean seeds artificially contamined with the pathogen were fumigated with the mixture of VOCs in sealed glass flasks for four and seven days. In the in vitro assays, the compounds 2-methyl-1-butanol and 3-methyl-1-butanol were the most active against $S$. sclerotiorum, completely inhibiting its mycelial growth at $0.8 \mu \mathrm{L} \mathrm{mL}^{-1}$, followed by the ethyl acetate, at $1.2 \mu \mathrm{L} \mathrm{mL}^{-1}$. Bean seeds fumigated with the VOCs at $3.5 \mu \mathrm{L} \mathrm{mL}^{-1}$ showed a $75 \%$ reduction in $S$. sclerotiorum incidence after four days of fumigation. The VOCs produced by $S$. cerevisiae have potential to control the pathogen in stored seeds.
\end{abstract}

Index terms: Phaseolus vulgaris, alternative control, fumigation, white mold, yeast.

\section{Potencial de compostos orgânicos voláteis antimicrobianos no controle de Sclerotinia sclerotiorum em sementes de feijão}

Resumo - O objetivo deste trabalho foi avaliar o potencial da mistura de compostos orgânicos voláteis (COVs), produzidos por Saccharomyces cerevisiae, no controle de Sclerotinia sclerotiorum in vitro e em sementes de feijão. O fungo fitopatogênico foi exposto, em placas de poliestireno, a uma atmosfera artificial que continha uma mistura de seis COVs, formada por álcoois (etanol, 3-metil-1-butanol, 2-metil-1-butanol e feniletilalcool) e ésteres (acetato de etila e octanoato de etila) nas proporções encontradas na atmosfera naturalmente produzida pela levedura. Sementes de feijão artificialmente contaminadas com o patógeno foram fumigadas com a mistura de COVs em frascos de vidro selados por quatro e sete dias. Nos experimentos in vitro, os compostos 2-metil-1-butanol e 3-metil-1-butanol foram os mais ativos sobre S. sclerotiorum, com inibição completa do crescimento micelial na concentração de $0,8 \mu \mathrm{L} \mathrm{mL}^{-1}$, seguidos pelo acetato de etila na concentração de $1,2 \mu \mathrm{L} \mathrm{mL}^{-1}$. As sementes de feijão fumigadas com os COVs na concentração de $3,5 \mu \mathrm{L} \mathrm{mL}^{-1}$ apresentaram $75 \%$ de redução da incidência de $S$. sclerotiorum após quatro dias de fumigação. Os COVs produzidos por $S$. cerevisiae possuem potencial de controle do patógeno em sementes armazenadas.

Termos de indexação: Phaseolus vulgaris, controle alternativo, fumigação, mofo-branco, levedura.

\section{Introduction}

Sclerotinia sclerotiorum (Lib.) de Bary is a broad host range soilborne fungus and the causal agent of white mold in many crops of economic importance. Boland \& Hall (1994) reported 75 families, 278 genera and 408 species as hosts of this pathogen, which causes one of the most serious and destructive diseases in irrigated crops.
S. sclerotiorum dissemination by infected seeds plays a key role in the infestation of areas previously free of the pathogen. The proposed tolerance index for this fungus in seed certification programs, in Brazil, is zero (Menten et al., 2006), since the occurrence of the pathogen in seeds, even at low rates, can cause large production losses, and once introduced and established in an area, its eradication is practically impossible in a short period of time. 
Seed treatment with fungicides is an important measure to control pathogens carried by them. However, this kind of control is not completely effective, especially if the pathogen is transported in the inner part of the seed. Problems associated with fungicide resistance and the consumers' perception on the potential impact of traditional practices of control on human health and environment have led farmers and researchers to consider alternative methods to plant disease control (Punja \& Utkhede, 2003).

During plant-pathogen interaction, microbial antagonists can interrupt some stages of the disease or the pathogen's life cycle. This can occur through parasitism, competition for space and nutrients, production of hydrolytic enzymes (Punja \& Utkhede, 2003) and through antimicrobial compounds (Vinale et al., 2006), including volatiles (Strobel, 2006).

Volatile organic compounds (VOCs) usually have low molecular weight and high vapor pressure. They are active at very low concentrations and belong to several chemical groups, such as alcohols, aldehydes, ketones, esters, lactones, terpenes and sulfur compounds (Wheatley, 2002). Because of their volatility, these compounds can travel large distances in a structurally heterogeneous environment composed of solids, liquids and gases (Wheatley, 2002), which is a major advantage for this kind of antimicrobial agent.

The VOCs have received limited attention in comparison to the antagonism caused by medium-diffusible compounds; however, new findings have recently brought these volatile metabolism products into focus. Most of the studies on the production of antimicrobial VOCs are related to Muscodor albus, Trichoderma spp. and Bacillus spp. (Humphris et al., 2002; Grimme et al., 2007; Leelasuphakul et al., 2008) controlling phytopathogenic and wood-decay fungi.

An alternative method for $S$. sclerotiorum control is seed fumigation by antimicrobial VOCs in closed chambers, during storage. Muscodor albus, an endophytic fungus isolated from the cinnamon tree, is a well-known producer of antimicrobial VOCs and has been tested to control several pathogens in infested soils, fruits and seeds in storage (Strobel, 2006). Natural and artificial mixtures of VOCs have inhibited by $100 \%$ the growth of several plant pathogens, including $S$. sclerotiorum, and effectively served as fumigants of fungal contaminated seeds (wheat, chickpea, corn, barley and canola) during storage. Propanoic acid, 2-methyl and several related esters were associated with VOCs bioactivity (Ezra \& Strobel, 2003).

Previous work has shown that the yeast Saccharomyces cerevisiae isolated from fermentation processes for fuel ethanol production produces VOCs that are able to inhibit the in vitro development of Guignardia citricarpa, the causal agent of citrus black spot (Fialho et al., 2010). That was the first known report on the production of VOCs by yeasts with antimicrobial activity against plant pathogens. The VOC composition was identified by gas chromatography with mass spectrometric detection (GC-MS) and the artificial mixture mimicked the effects of the natural VOCs produced by yeast (Fialho et al., 2010).

The objective of this work was to evaluate the potential of an artificial mixture of volatile organic compounds, made of six compounds from $S$. cerevisiae, to control S. sclerotiorum in vitro and in inoculated bean seeds.

\section{Materials and Methods}

The effect of the VOC mixture was evaluated in vitro in separated experiments. The tested plant pathogens evaluated were: S. sclerotiorum, Fusarium oxysporum f. sp. phaseoli and Colletotrichum lindemuthianum, which were isolated from infected bean seeds, and maintained at the Departamento de Fitopatologia e Nematologia da Escola Superior de Agricultura Luiz de Queiroz, Universidade de São Paulo, Piracicaba, SP, Brazil. Based on the results obtained by GC-MS analysis of the gaseous atmosphere produced by S. cerevisiae (Fialho et al., 2010), an artificial mixture of VOCs was made using authentic commercial standards (Sigma-Aldrich, St. Louis, Missouri, USA). The six compounds used were positively identified in the mixture, and the concentration of each one of them was based on its relative proportion (\%) in relation to all other components (Table 1).

Two section-divided polystyrene plates $(90 \times 15 \mathrm{~mm}$, 60 mL volume) (J. Prolab, São José dos Pinhais, Paraná, Brazil) were used for bioassays. A $5 \mathrm{~mm}$ agar plug with the mycelium of each phytopathogen was transferred to one side of the plate, containing $10 \mathrm{~mL}$ of potato dextrose agar (PDA) medium. A piece of sterile cotton wool, containing $100 \mu \mathrm{L}\left(2 \mu \mathrm{L} \mathrm{mL}^{-1}\right.$ air space $)$ of the artificial mixture, was added to the opposite side of the plate. The control consisted of plates containing 
the pathogen in the absence of the artificial mixture. The plates were immediately sealed with parafilm and kept at $26^{\circ} \mathrm{C}$ under a $12 \mathrm{~h}$ photoperiod (fluorescent light). The mycelial growth was evaluated based on the average between the two opposing measurements when the colony in control plates reached the borders. At the end of the assays, the agar plugs were transferred to the plates containing PDA medium in the absence of the artificial mixture in order to verify fungal viability. The assays were carried out in five replicates.

Due to the higher in vitro susceptibility of $S$. sclerotiorum to the VOCs and to its economical impact on several crops, in another experiment, bean seeds with $S$. sclerotiorum were fumigated with the artificial mixture of VOCs. For the artificial inoculation, bean seeds (Phaseolus vulgaris L.) from the cultivar Carioca, free of $S$. sclerotiorum, were used. Seeds were submitted to surface sterilization with sodium hypochlorite (1\%) for $2 \mathrm{~min}$, washed in sterile distilled water and dried at room temperature for $24 \mathrm{~h}$. For inoculation, seeds were placed in Petri dishes with PDA medium, colonized with a five days old S. sclerotiorum culture (Peres et al., 2002). The incubation was performed at $21^{\circ} \mathrm{C}$, in the dark, for $48 \mathrm{~h}$. Seeds were dried at room temperature for $72 \mathrm{~h}$, mixed with healthy seeds in the proportion $1: 2(\mathrm{w} / \mathrm{w})$, and homogenized.

For fumigation, $200 \mathrm{~g}$ of seeds were placed in $310 \mathrm{~mL}$ glass flasks, and different volumes of the artificial mixture were added to a piece of cotton wool fixed to the cap in order to obtain the desired concentrations inside the flasks $\left(0.875,1.75\right.$ and $3.5 \mu \mathrm{L} \mathrm{mL}{ }^{-1}$ air space). The flasks were closed, sealed with parafilm and stored at $25^{\circ} \mathrm{C}$ in the dark, for four and seven days. The control treatment consisted of flasks without the

Table 1. Composition of the volatile organic compounds produced by Saccharomyces cerevisiae.

\begin{tabular}{lc}
\hline Compound $^{(1)}$ & Relative \% \\
\hline Ethanol & 85.3 \\
Nonidentified & 1.5 \\
Ethyl acetate & 1.8 \\
3-methyl-1-butanol & 6.9 \\
2-methyl-1-butanol & 2.4 \\
Phenylethyl alcohol & 0.7 \\
Ethyl octanoate & 1.4 \\
\hline
\end{tabular}

(1)Identification by gas chromatography with mass spectrometric detection (GC-MS) (Fialho et al., 2010). artificial mixture. After the fumigation period, the seeds were removed from the flasks, placed in paper bags and stored at $4^{\circ} \mathrm{C}$ until microbial analysis.

The seeds were submitted to seed health test for detection of $S$. sclerotiorum using the blotter method. Two hundred seeds per treatment (four replicates of 50 seeds for each treatment) were analyzed. Ten seeds were distributed equidistantly inside polystyrene plates $(90 \times 15 \mathrm{~mm})$ on three sheets of filter paper previously moistened with sterile distilled water. The plates were wrapped in paper and placed inside a dark plastic bag to maintain humidity and prevent from light, and kept at $10^{\circ} \mathrm{C}$ (Koch \& Menten, 2000). The evaluation was performed after 7 and 14 days of incubation, by observing the development of typical mycelium and the formation of sclerotia by the pathogen.

To evaluate the individual effect of each compound in the VOC mixture, another in vitro assay was carried out, exposing the pathogen to the different VOCs at $1 \mu \mathrm{L} \mathrm{mL}^{-1}$ air space. In another assay, the most bioactive compounds were tested at different concentrations ( 0.0 to $2.0 \mu \mathrm{L} \mathrm{mL}^{-1}$ air space). The control consisted of plates with the pathogen in the absence of volatiles. In both assays, the plates were sealed, incubated and evaluated as described above. Four replicates were used for each treatment.

The experimental design used in this study was completely randomized, and the means were compared by the Tukey test, at $1 \%$ probability.

\section{Results and Discussion}

S. sclerotiorum, C. lindemuthianum and F. oxysporum f. sp. phaseoli used in the previous in vitro control experiment, showed different susceptibility to the artificial mixture of VOCs used (Table 2). The highest inhibition level was observed on $S$. sclerotiorum (77\% of inhibition), while the mycelial growth of C. lindemuthianum and F. oxysporum f. sp. phaseoli was

Table 2. Influence of the volatile organic compounds artificial mixture on the in vitro development of bean pathogens ${ }^{(1)}$.

\begin{tabular}{lcc}
\hline Fungus & \multicolumn{2}{c}{ Mycelial growth $(\mathrm{cm})$} \\
\cline { 2 - 3 } & Control & Volatiles \\
\hline Sclerotinia sclerotiorum & $5.51 \mathrm{a}$ & $1.29 \mathrm{~b}$ \\
Colletotrichum lindemuthianum & $4.43 \mathrm{a}$ & $1.55 \mathrm{~b}$ \\
Fusarium oxysporum & $4.48 \mathrm{a}$ & $3.00 \mathrm{~b}$ \\
\hline
\end{tabular}

${ }^{(1)}$ Means followed by equal letters, in the lines, do not differ by the Tukey test, at $1 \%$ probability. 
inhibited 65 and 33\%, respectively. Fialho et al. (2010), using the same artificial mixture of VOCs, verified that the mycelial growth of G. citricarpa was reduced more than $87 \%$. Fusarium spp. seems to be more resistant to antimicrobial volatiles. Stinson et al. (2003) reported that the VOCs produced by Gliocladium $\mathrm{sp}$. fungus or their artificial mixtures inhibited $F$. oxysporum only partially. Similarly, F. solani was the less susceptible among several tested fungi to the VOCs produced by M. albus (Strobel et al., 2001). Atmosukarto et al. (2005) studied the susceptibility of plant fungal pathogens, from several taxonomic groups, to the artificial mixture of VOCs produced by M. albus. The artificial mixture was able to inhibit $100 \%$ of the mycelial growth of all tested microorganisms, except $F$. culmorum. In that study, Colletotrichum spp. also showed less susceptibility to the VOCs, since $C$. coccodes and C. gloeosporioides remained alive despite the total inhibition of mycelial growth. The same behavior was observed by Mercier \& Jiménez (2004) for C. coccodes and C. acutatum when exposed to the VOCs produced by M. albus.

A possible determinant factor in the sensibility differences among microorganisms to antimicrobial compounds, including alcohols and esters, is the plasma membrane composition and the resistance mechanisms used to counteract deleterious effects, such as the ability to change the composition and structure of the plasma membrane (Weber \& Bont, 1996), and processes of detoxification, efflux transport and storage (Duffy et al., 2003). However, the particular mechanisms involved in the protection against volatiles are not yet known in detail.

In the control treatment, the white mold incidence in bean seeds was $29.5 \%$ (Table 3 ). The fumigation with the VOCs at $0.875 \mu \mathrm{L} \mathrm{mL}^{-1}$ and $1.75 \mu \mathrm{L} \mathrm{mL}-1$

Table 3. Influence of the concentration of volatile organic compounds artificial mixture on the incidence of Sclerotinia sclerotiorum artificially inoculated in bean seeds ${ }^{(1)}$.

\begin{tabular}{lcc}
\hline Dose & \multicolumn{2}{c}{ Incidence $(\%)$} \\
\cline { 2 - 3 }$\left(\mu \mathrm{L} \mathrm{mL}^{-1}\right)$ & Four days & Seven days \\
\hline Control & $29.5 \mathrm{Aa}$ & $29.5 \mathrm{Aa}$ \\
0.875 & $19.5 \mathrm{Ba}$ & $20.0 \mathrm{Ba}$ \\
1.75 & $20.0 \mathrm{Ba}$ & $17.0 \mathrm{Ba}$ \\
3.5 & $17.0 \mathrm{Ca}$ & $16.5 \mathrm{Ca}$ \\
\hline
\end{tabular}

${ }^{(1)}$ Means followed by equal letters, uppercase in the columns and lowercase in the lines, do not differ by the Tukey test, at $1 \%$ probability. caused significant incidence reduction. Nevertheless, the highest fungal reduction (75\%) was observed at $3.5 \mu \mathrm{L} \mathrm{mL} \mathrm{m}^{-1}$. There was no statistical difference in relation to the exposure time (four or seven days).

Although the seed treatment under these conditions did not eradicate the fungus, the fumigation with the artificial mixture of VOCs was considered effective. The fungus incidence was about $30 \%$, but in natural conditions its incidence is much lower, around $0.2 \%$ on average (Menten et al., 2006). Since the pathogen was artificially inoculated in the seeds, the fungus may have penetrated more deeply into the seed and the VOCs might not have reached all pathogen. Poor quality or heavily contaminated seeds will most likely not be kept for use. However, seeds with slight contamination would normally be treated in closed chambers during storage to eliminate unwanted fungal contamination. According to Ezra \& Strobel (2003), the fumigation of wheat, corn, barley, canola and chickpea seeds with the VOCs produced by M. albus contributed to the incidence reduction of the natural infection with the fungi Aspergillus sp., Penicillium sp., Fusarium sp. Leptosphaeria maculans, and A. ochraceus, artificially inoculated in wheat seeds. The authors found that the treatment was ineffective in seeds with high fungal contamination, probably due to deeper infection.

In relation to the individual effect of each compound of the VOC mixture (Table 4), the mycelial growth of the phytopathogen was inhibited nearly $100 \%$ by the compounds 2-methyl-1-butanol and 3-methyl-1-butanol. The ethyl acetate showed high inhibitory activity (87\%), while the compounds ethyl octanoate and phenylethyl alcohol showed lower activity on the fungus (34 and $8 \%$ of inhibition,

Table 4. Influence of the different volatile organic compounds and of their mixture (1 $\mu \mathrm{L} \mathrm{mL}^{-1}$ air space) on the in vitro development of Sclerotinia sclerotiorum ${ }^{(1)}$.

\begin{tabular}{lc}
\hline Compound & Mycelial growth $(\mathrm{cm})$ \\
\hline Control & $5.25 \mathrm{a}$ \\
Ethanol & $5.03 \mathrm{a}$ \\
Phenylethyl alcohol & $4.82 \mathrm{ab}$ \\
Artificial mixture & $4.35 \mathrm{~b}$ \\
Ethyl octanoate & $3.45 \mathrm{c}$ \\
Ethyl acetate & $0.70 \mathrm{~d}$ \\
2-methyl-1-butanol & $0.07 \mathrm{e}$ \\
3-methyl-1-butanol & $0.05 \mathrm{e}$ \\
\hline${ }^{(1)}$ Means followed by equal letters do not differ by the Tukey test, at $1 \%$ \\
probability.
\end{tabular}


respectively). The ethanol did not affect significantly the fungal growth, despite being the main component (85\%) of the mixture of VOCs. The VOCs 2-methyl-1-butanol, 3-methyl-1-butanol and ethyl acetate, identified in $S$. cerevisiae, were the main ones responsible for the antimicrobial activity on $S$. sclerotiorum. This information is important to develop an improved synthetic mixture for the pathogen control in seeds.

The pathogen $S$. sclerotiorum was completely inhibited by the alcohols 2-methyl-1-butanol and 3-methyl-1-butanol at $0.8 \mu \mathrm{L} \mathrm{mL} \mathrm{m}^{-1}$, and the ethyl acetate had the same effect at $1.2 \mu \mathrm{L} \mathrm{mL}^{-1}$ (Figure 1). Independently of the concentration tested, the compounds exhibited no fungicide activity, and the fungus resumed growth after the transfer to new PDA medium in the absence of volatiles. The compounds tested alone, but in higher concentrations than those naturally produced by yeast, were able to completely suppress fungal development. However, the synergism between the different components of the mixture cannot be discarded. The fungus $M$. albus produces a complex mixture of about 30 VOCs (Strobel, 2006). The use of artificial mixtures showed that the presence of 3-methyl-1-butanol, naphthalene and propanoic acid was necessary to keep the inhibitory activity against the pathogens S. sclerotiorum, Pythium ultimum and Rhizoctonia solani, indicating the synergy between the different components of the mixture (Ezra et al., 2004).

Very little is known about the microbial volatile mode of action on the control of fungi. It is likely that volatiles act by changing protein expression (Humphris et al., 2002) and the activity of specific enzymes

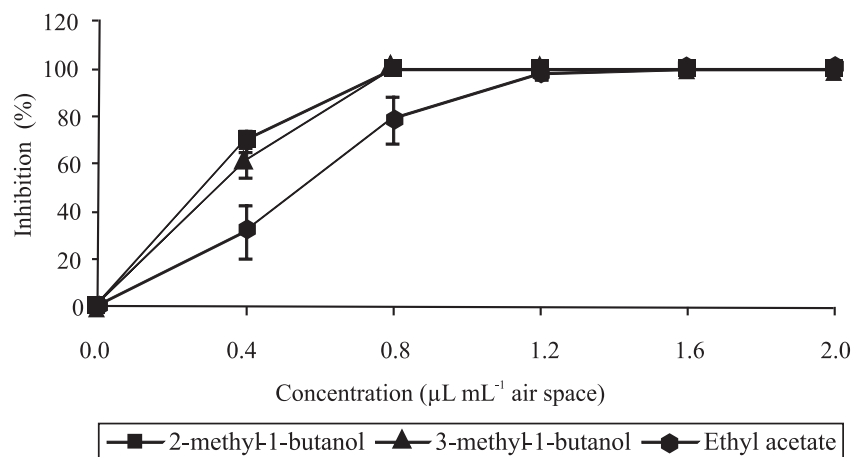

Figure 1. Mean $\pm \mathrm{SD}$ of Sclerotinia sclerotiorum growth inhibition, in comparison to the control treatment, caused by different concentrations of 2-methyl-1-butanol, 3-methyl-1-butanol and ethyl acetate.
(Wheatley, 2002), which may reflect on growth. Another probable primary site of action is the plasma membrane, in which the accumulation of solvents could affect the organization and stability of the lipid bilayer, and increase the proton permeability leading to the dissipation of the proton motive force. Damage to the plasma membrane causes loss of essential metabolites, changes in the control of the internal $\mathrm{pH}$, reduces the activity of membrane-associated enzymes (Weber \& Bont, 1996; McDonnell \& Russell, 1999), and impairs nutrient uptake (Jacobsen, 1995). The compounds 2-methyl-1-butanol and 3-methyl-1-butanol have high affinity for the plasma membrane and, therefore, higher toxicity when compared to less lipophilic compounds, such as ethanol, which has toxic effects only in high concentrations (Weber \& Bont, 1996).

\section{Conclusions}

1. The artificial mixture of volatile organic compounds produced by Saccaromices cerevisiae is able to inhibit the in vitro development of Sclerotinia sclerotiorum.

2. Fumigation with the volatile compounds reduces significantly the incidence of $S$. sclerotiorum in bean seeds.

3. The compounds 2-methyl-1-butanol, ethyl acetate and 3-methyl-1-butanol are the main ones responsible for the antimicrobial activity against the phytopathogen.

\section{Acknowledgments}

To Coordenação de Aperfeiçoamento de Pessoal de Nível Superior and Conselho Nacional de Desenvolvimento Científico e Tecnológico, for the support.

\section{References}

ATMOSUKARTO, I.; CASTILLO, U.; HESS, W.M.; SEARS, J.; STROBEL, G. Isolation and characterization of Muscodor albus I-41.3s, a volatile antibiotic producing fungus. Plant Science, v.169, p.854-861, 2005.

BOLAND, G.; HALL, R. Index of plant hosts to Sclerotinia sclerotiorum. Canadian Journal of Microbiology, v.16, p.93-108, 1994.

DUFFY, B.; SCHOUTEN, A.; RAAIJMAKERS, J.M. Pathogen self-defense: mechanisms to counteract microbial antagonism. Annual Review of Phytopathology, v.41, p.501-538, 2003. 
EZRA, D.; HESS, W.M.; STROBEL, G.A. New endophytic isolates of Muscodor albus, a volatile-antibiotic-producing fungus. Microbiology, v.150, p.4023-4031, 2004.

EZRA, D.; STROBEL, G.A. Effect of substrate on the bioactivity of volatile antimicrobials produced by Muscodor albus. Plant Science, v.165, p.1229-1238, 2003.

FIALHO, M.B.; TOFFANO, L.; PEDROSO, M.P.; AUGUSTO, F.; PASCHOLATI, S.F. Volatile organic compounds produced by Saccharomyces cerevisiae inhibit the in vitro development of Guignardia citricarpa, the causal agent of citrus black spot. World Journal of Microbiology and Biotechonology, v.26, p.925-932, 2010 .

GRIMME, E.; ZIDACK, N.K.; SIKORA, R.A.; STROBEL, G.A.; JACOBSEN, B.J. Comparison of Muscodor albus volatiles with a biorational mixture for control of seedling diseases of sugar beet and root-knot nematode on tomato. Plant Disease, v.91, p.220-225, 2007.

HUMPHRIS, S.N.; BRUCE, A.; BUULTJENS, T.E.J.; WHEATLEY, R.E. The effects of volatile secondary metabolites on protein synthesis in Serpula lacrymans. FEMS Microbiology Letters, v.210, p.215-219, 2002.

JACOBSEN, T. Acute toxicity of 16 water-soluble chemicals to the fungus Geotrichum candidum measured by reduction in glucose uptake. Toxicology in Vitro, v.9, p.169-173, 1995.

KOCH, E.F.A.; MENTEN, J.O.M. Método alternativo para detecção de Sclerotinia sclerotiorum em sementes de feijoeiro. Summa Phytopathologica, v.26, p.276-278, 2000.

LEELASUPHAKUL, W.; HEMMANEEA, P.; CHUENCHITT, S. Growth inhibitory properties of Bacillus subtilis strains and their metabolites against the green mold pathogen (Penicillium digitatum Sacc.) of citrus fruit. Postharvest Biology and Technology, v.48, p.113-121, 2008.

MCDONNELL, G.; RUSSELL, A.D. Antiseptics and disinfectants: activity, action, and resistance. Clinical Microbiology Reviews, v.12, p.147-179, 1999.
MENTEN, J.O.M.; MORAES, M.H.D. de; NOVEMBRE, A.D. da L.C.; ITO, M.A. Qualidade das sementes de feijão no Brasil. 2006. Disponível em: <http://www.infobibos.com/Artigos/2006_2/ SementesFeijao/index.htm>. Acesso em:10 fev. 2011.

MERCIER, J.; JIMÉNEZ, J.I. Control of fungal decay of apples and peaches by the biofumigant fungus Muscodor albus. Postharvest Biology and Technology, v.31, p.1-8, 2004.

PERES, A.P.; NASSER, L.C.; MACHADO, J.C. Use of semiselective media for detection of Sclerotinia sclerotiorum on bean and soybean seeds. Fitopatologia Brasileira, v.27, 123-127, 2002.

PUNJA, Z.K.; UTKHEDE, R.S. Using fungi and yeasts to manage vegetable crop diseases. Trends in Biotechnology, v.21, p.400-407, 2003.

STINSON, M.; EZRA, D.; HESS, W.M.; SEARS, J.; STROBEL, G. An endophytic Gliocladium sp. of Eucryphia cordifolia producing selective volatile antimicrobial compounds. Plant Science, v.165, p.913-922, 2003.

STROBEL, G. Muscodor albus and its biological promise. Journal of Industrial Microbiology \& Biotechnology, v.33, p.514-522, 2006.

STROBEL, G.A.; DIRKSE E.; SEARS, J.; MARKWORTH, C. Volatile antimicrobials from Muscodor albus, a novel endophytic fungus. Microbiology, v.147, p.2943-2950, 2001.

VINALE, F.; MARRA, R.; SCALA, F.; GHISALBERTI, E.L.; LORITO, M.; SIVASITHAMPARAM, K. Major secondary metabolites produced by two commercial Trichoderma strains active against different phytopathogens. Letters in Applied Microbiology, v.43, p.143-148, 2006.

WEBER, F.J.; BONT, J.A. de. Adaptation mechanisms of microorganisms to the toxic effects of organic solvents on membranes. Biochimica et Biophysica Acta, v.1286, p.225-245, 1996.

WHEATLEY, R.E. The consequences of volatile organic compound mediated bacterial and fungal interactions. Antonie van Leeuwenhoek, v.81, p.357-364, 2002.

Received on September 22, 2010 and accepted on December 20, 2010 